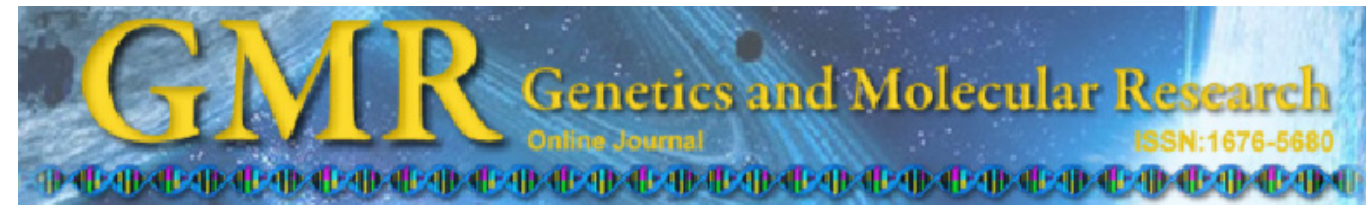

\title{
Rapid morphological changes in populations of hybrids between Africanized and European honey bees
}

\author{
T.M. Francoy ${ }^{1}$, L.S. Gonçalves ${ }^{2,3,4}$ and D. De Jong ${ }^{5}$ \\ ${ }^{1}$ Escola de Artes, Ciências e Humanidades, Universidade de São Paulo, \\ São Paulo, SP, Brasil \\ ${ }^{2}$ Departamento de Biologia, \\ Faculdade de Filosofia, Ciências e Letras de Ribeirão Preto, \\ Universidade de São Paulo, Ribeirão Preto, SP, Brasil \\ ${ }^{3}$ Centro Tecnológico de Apicultura e Meliponicultura, \\ Universidade Federal Rural do Semi-Árido, Mossoró, RN, Brasil \\ ${ }^{4}$ Departamento de Ciências Animais, \\ Universidade Federal Rural do Semi-Árido, Mossoró, RN, Brasil \\ ${ }^{5}$ Departamento de Genética, Faculdade de Medicina de Ribeirão Preto, \\ Universidade de São Paulo, Ribeirão Preto, SP, Brasil \\ Corresponding author: T.M. Francoy \\ E-mail: tfrancoy@usp.br
}

Genet. Mol. Res. 11 (3): 3349-3356 (2012)

Received August 2, 2012

Accepted August 16, 2012

Published September 17, 2012

DOI http://dx.doi.org/10.4238/2012.September.17.5

\begin{abstract}
African honey bees, introduced to Brazil in 1956, rapidly dominated the previously introduced European subspecies. To better understand how hybridization between these different types of bees proceeded, we made geometric morphometric analyses of the wing venation patterns of specimens resulting from crosses made between Africanized honey bees (predominantly Apis mellifera scutellata) and Italian honey bees (A. mellifera ligustica) from 1965 to 1967, at the beginning of the Africanization process, in an apiary about $150 \mathrm{~km}$ from the original introduction site. Two virgin queens reared from an Italian parental were instrumentally inseminated with semen from drones from an Africanized parental. Six $F_{1}$ queens from one of these colonies were
\end{abstract}


open mated with Africanized drones. Resultant $\mathrm{F}_{1}$ drones were backcrossed to 50 Italian and 50 Africanized parental queens. Five backcross workers were collected from each of eight randomly selected colonies of each type of backcross ( $\mathrm{N}=5$ bees $\times 8$ colonies $\times 2$ types of backcrosses). The $\mathrm{F}_{1}$ progeny (40 workers and 30 drones) was found to be morphologically closer to the Africanized than to the European parental $(\mathrm{N}=20$ drones and 40 workers, each); Mahalanobis square distances $=21.6$ versus 25.8, respectively, for the workers, and 39.9 versus 46.4 , respectively, for the drones. The worker progenies of the backcrosses $(\mathrm{N}=40$, each) were placed between the respective parental and the $\mathrm{F}_{1}$ progeny, although closer to the Africanized than to the Italian parentals (Mahalanobis square distance $=6.2$ versus 12.1, respectively). Consequently, the most common crosses at the beginning of the Africanization process would have generated individuals more similar to Africanized than to Italian bees. This adds a genetic explanation for the rapid changes in the populational morphometric profile in recently colonized areas. Africanized alleles of wing venation pattern genes are apparently dominant and epistatic.

Key words: Africanized bee; Apis mellifera ligustica; Wing morphology; Multivariate statistics; Geometric morphometrics

\section{INTRODUCTION}

The European races of Apis mellifera were not found to be productive in Brazil and were poorly adapted to the hotter regions of the country. In an attempt to overcome these limitations, the African subspecies A. m. scutellata (previously considered to be A. $m$. adansonii) was introduced to Brazil in 1956 (Kerr, 1967). After the escape of swarms from 26 hives, these bees started to cross with the previously introduced European subspecies, generating the socalled Africanized honey bee (Gonçalves, 1974), which rapidly spread throughout most of the Americas (Sheppard et al., 1991; Pinto et al., 2005).

As this new bee was totally unknown, there was considerable interest in Africanized honey bee identification. Morphometric analyses were widely used. Daly and Balling (1978) developed a procedure for Africanized bee identification, based on discriminant analysis of 25 morphometric characters; this method was later improved with computer-assisted measurements (Daly et al., 1982). A simplification of these procedures resulted in the "Fast Africanized Bee Identification" system (FABIS) for preliminary identification in the field (Rinderer et al., 1986). Nowadays, due to advances in morphometric analyses, Africanized bees can be identified even with features measured in a single wing cell (Francoy et al., 2006) and also by overall wing venation patterns (Francoy et al., 2008, 2009).

Although there has been considerable improvement in morphometric and other techniques that allow us to characterize these bees, relatively few studies have been made that characterize Africanized and European progenitors and crosses between them. Rinderer et al. (1990) compared morphometric measurements of workers of Africanized and European bees and of their $F_{1}$ progeny. Rinderer et al. (1993) also used large reference populations to develop patterns for the recognition of intermediate individuals; they intercrossed Africanized and Eu- 
ropean bees, producing 192 hybrid colonies. Based on morphometric analyses, they concluded that most of these hybrid colonies were intermediate (midway) between the groups.

In order to better understand the beginning of the Africanization process in Brazil, we morphometrically characterized workers and drones of Africanized and European bees and their $\mathrm{F}_{1}$ progeny, as well as workers of the backcrosses, using geometric morphometric analysis. Our objective was to determine the relative influence of each type of bee on the $F_{1}$ and backcross progeny, in order to generate information relevant to our understanding of the process of ecological dominance of African over European bees.

\section{MATERIAL AND METHODS}

\section{Crosses and samples}

We examined bees that had been collected in a controlled mating experiment conducted from 1965 to 1967 in Ribeirão Preto, SP, Brazil (2110'S 46 51'W) (Gonçalves, 1970), about $150 \mathrm{~km}$ from where the African bees were originally introduced, in Rio Claro, SP $\left(22^{\circ} 24^{\prime} \mathrm{S} 47^{\circ} 34^{\prime} \mathrm{W}\right)$. Two colonies were used as parental types; the initial crosses were made with queens and drones produced by these colonies. One of the colonies was headed by an Africanized honey bee queen from Ribeirão Preto, SP, Brazil, and the other one had an $A$. $m$. ligustica queen imported from the United States of America. Both queens were naturally mated at their origin. Forty workers were collected from each of these colonies (Figure 1).

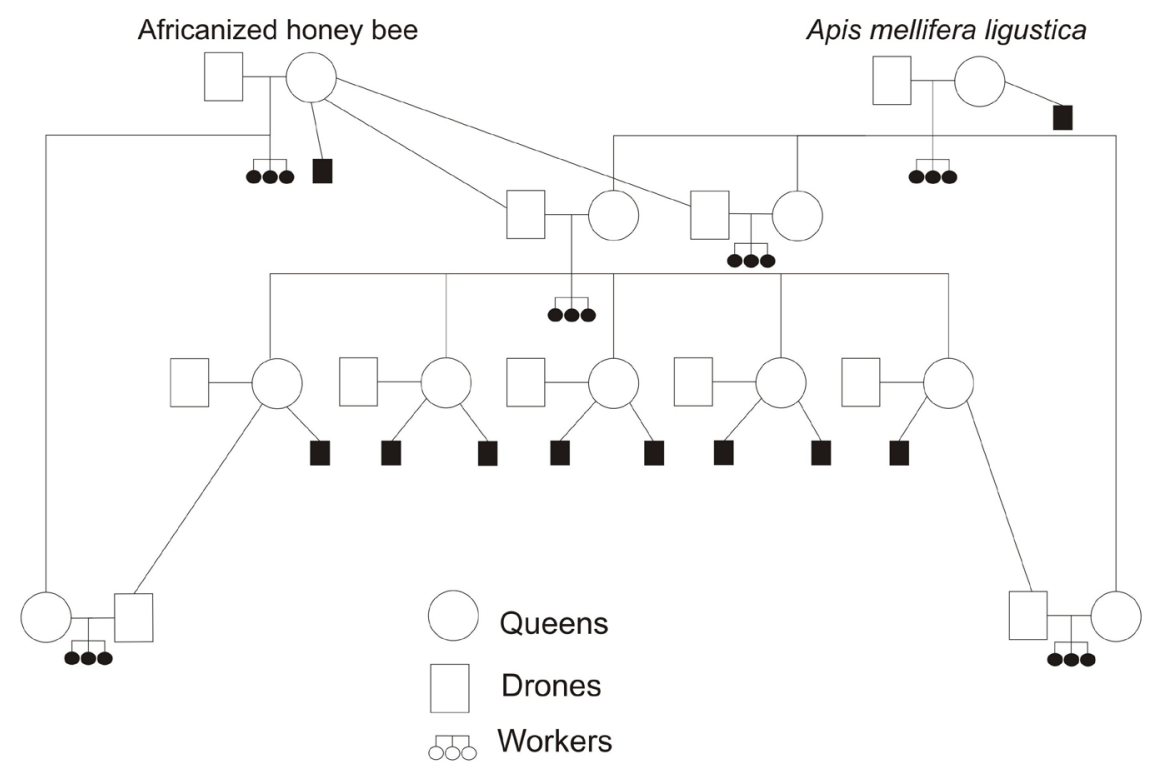

Figure 1. Schematic of the mating system used for crosses and backcrosses between Africanized and European honey bees. The samples collected in each generation are marked as filled symbols. The $\mathrm{F}_{1}$ drones backcrossed to the parental queens came from all of the original six $F_{1}$ queens; this origin is only shown here for two of the five $F_{1}$ queens that provided the drones for morphometric analyses, to avoid cluttering the diagram $(\mathrm{N}=40$ workers from each of the two parentals and the two types of backcross, as well as from the $\mathrm{F}_{1}$ generation; $\mathrm{N}=20$ drones from each of the parentals and $30 \mathrm{~F}_{1}$ drones). 
Two Italian queens, produced from the European parental colony, were instrumentally inseminated with the semen of one parental Africanized drone each. Samples of $20 \mathrm{~F}_{1}$ workers were collected from each of the colonies headed by these queens (Figure 1). Six hybrid queens were produced from one of these $\mathrm{F}_{1}$ colonies; these queens were naturally mated and provided the $\mathrm{F}_{1}$ drones used in the backcrosses. We randomly selected five workers from each of eight backcrosses of $F_{1}$ hybrid drones to parental European queens and eight backcrosses to parental Africanized queens (Figure 1). The original material, collected from 1965 to 1967 , included 50 backcrosses to each parental. Twenty drones were collected from each parental colony, and six $\mathrm{F}_{1}$ drones that had been produced by each of five of the original six $F_{1}$ queens were also collected (Figure 1). Only these five queens were included in the analysis, as the stored drones from one of the original colonies were damaged and were not suitable for our investigation.

\section{Wing preparation and shape analysis through geometric morphometrics}

The right forewings of all individuals were mounted between microscope slides and photographed using a digital camera attached to a stereomicroscope. We plotted 19 homologous landmarks at the wing vein intersections, as in Francoy et al. (2008), using the tpsDig version 2.04 software (Rohlf, 2005a); the images were Procrustes aligned and the centroid size and the relative warps were extracted using the tpsRelw version 1.42 software (Rohlf, 2005b).

The data were analyzed using univariate and multivariate methods. Significant univariate $F$ values $(\alpha=0.05)$ were used to identify the wing parameters that contributed most to group discrimination. A discriminant analysis of the wing parameters was carried out for both workers and drones to determine the degree of separation among the groups, using Mahalanobis square distances between the centroids of the proposed groups.

\section{RESULTS}

\section{Drones}

The analysis generated 34 relative warps, plus the centroid size. Among these 35 measures, 11 relative warps significantly $(\mathrm{P}<0.05)$ contributed to the separation of the three groups (Africanized, Italian, and $F_{1}$ hybrids). Based on multivariate analysis of variance (MANOVA) of the 35 characteristics, there were differences among the three groups (Wilk's $\lambda=0.01661, \mathrm{P}<0.00001)$. The first two relative warps accounted for $39.71 \%$ of the total variability, $27.41 \%$ in the first relative warp and $12.30 \%$ in the second relative warp. A postMANOVA discriminant analysis showed that the Mahalanobis square distances from each of the centroids of the groups to the other centroids were highly significant $(\mathrm{P}<0.0000001)$. The Mahalanobis distances between the centroids were: Africanized $x$ Italian $=39.19$, Africanized $\mathrm{x}_{1}$ hybrid $=39.89$ and Italian $\mathrm{x}_{1}$ hybrid $=46.42$. A graphical distribution of the three groups based on canonical analysis of the data showed that the groups were well separated; the position of the $\mathrm{F}_{1}$ drones was intermediate, but they were significantly closer to the Africanized drones (Figure 2). The linear discriminant functions were able to distinguish $100 \%$ of the individuals in the three groups. 


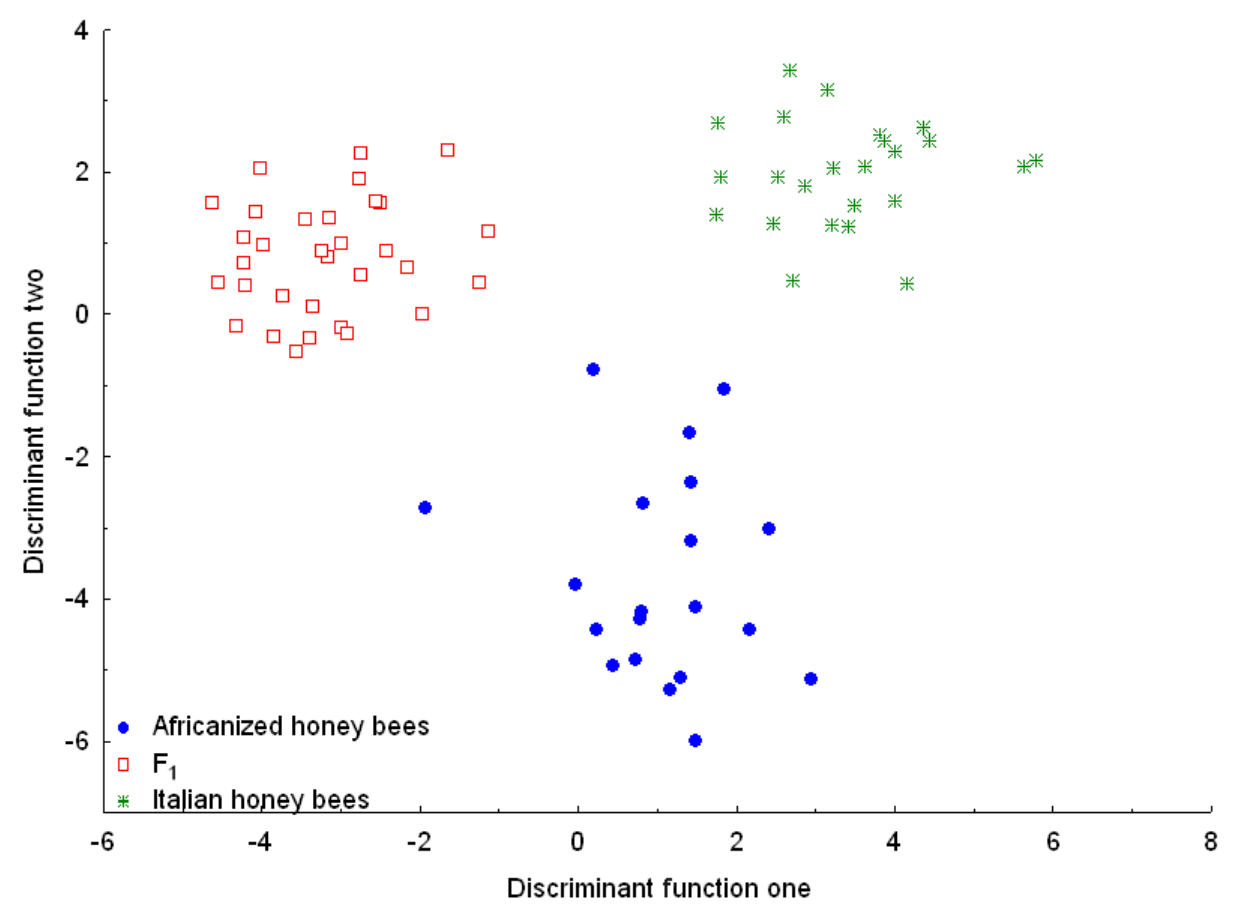

Figure 2. Discriminant analysis of the wing characters of the Africanized and Italian parental drones and of the $F_{1}$ queen-derived drones ( $\mathrm{F}_{1}$ drones).

\section{Workers}

Based on MANOVA of the workers' characteristics, there were significant differences among the five groups (Africanized and Italian parentals, $\mathrm{F}_{1}$, and backcrosses to the two parentals; Wilk's $\lambda=0.02169, \mathrm{P}<0.00001)$. Among the 35 traits, 22 relative warps and the centroid size significantly $(\mathrm{P}<0.05)$ contributed to the groups' separation. The first two relative warps explained $34.98 \%$ of the data variability, $20.23 \%$ by the first relative warp and $14.75 \%$ by the second one. Based on post-MANOVA discriminant analysis, the Mahalanobis square distance between the centroids indicated that each group was significantly different from the other four groups at $\mathrm{P}<0.0000001$, except for the $\mathrm{F}_{1} \mathrm{x}$ Africanized backcross, which was significant at $\mathrm{P}<0.00009$. The most distant groups were the two parental types (Figure 3). The $\mathrm{F}_{1}$ samples were significantly closer to the Africanized than to the Italian parentals, and the backcrosses were placed between the respective parental type and the $\mathrm{F}_{1}$ progeny. The Mahalanobis square distances (Table 1) and the graphical distribution of the five groups based on canonical analysis (Figure 3 ) show that the Africanized parental, the $\mathrm{F}_{1}$ progeny and the Africanized backcross are slightly more difficult to distinguish from each other than are the Italian parental and the Italian backcross.

Linear discriminant functions were able to correctly classify $89.94 \%$ of the individuals. The lowest rates of correct classifications were found in the $\mathrm{F}_{1}$ and in the Africanized backcross, with 85.71 and $83.78 \%$, respectively (see Figure 3). 


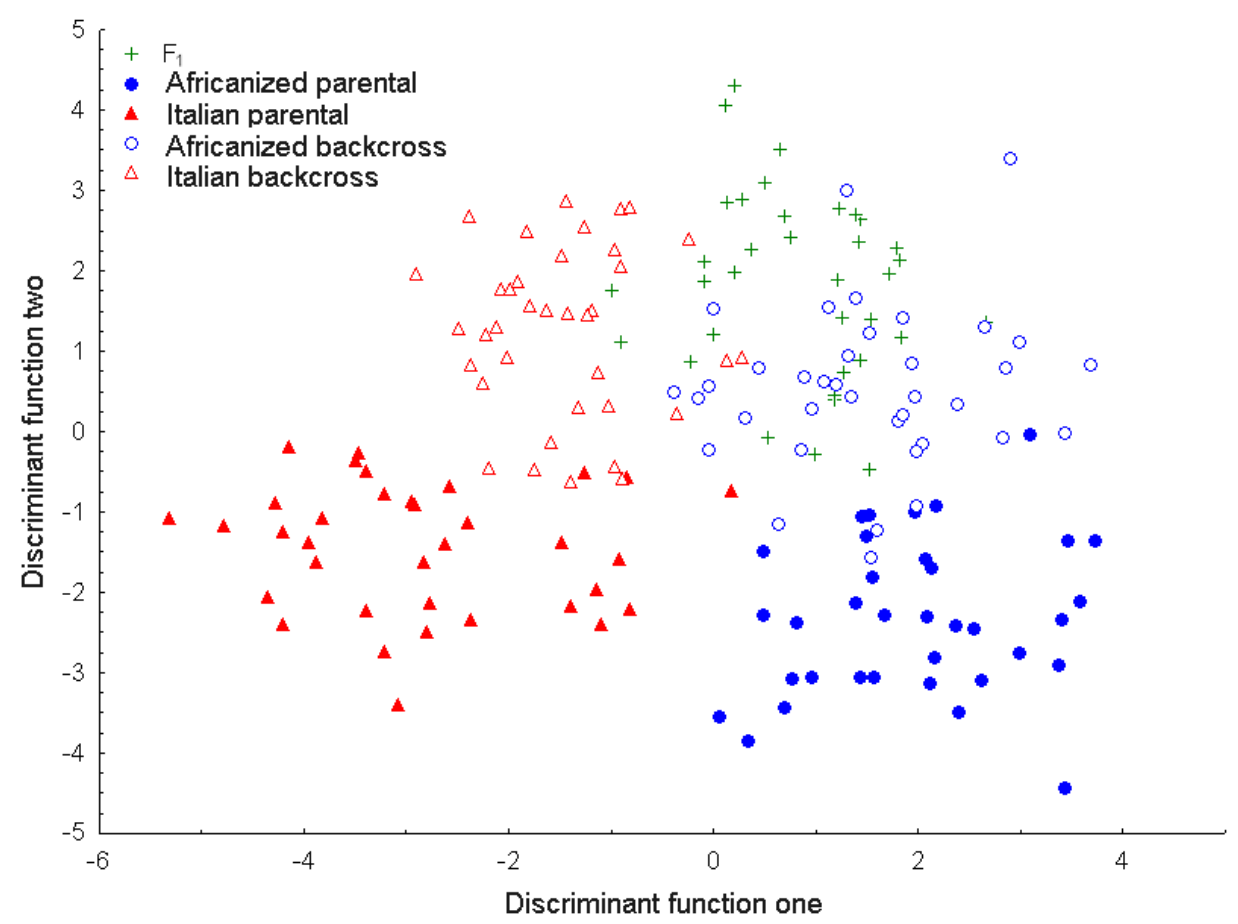

Figure 3. Discriminant analysis of the wing characters of the Africanized and Italian parental, $\mathrm{F}_{1}$ and backcross workers.

Table 1. Mahalanobis square distances between the centroids of the honey bee worker groups, based on discriminant analysis of wing characters.

\begin{tabular}{lcccc}
\hline & $\mathrm{F}_{1}$ hybrid & Africanized parental & Italian parental & Africanized backcross \\
\hline Africanized parental & 21.59 & & & \\
Italian parental & 25.83 & 27.44 & & \\
Africanized backcross & 6.19 & 12.90 & 24.70 & 15.79 \\
Italian backcross & 12.09 & 26.14 & 15.18 & \\
\hline
\end{tabular}

\section{DISCUSSION}

One of the most remarkable characteristics of the honey bees found in areas recently colonized by Africanized honey bees is the rapid loss of European features, mainly evidenced by changes in the bees' behavior and morphology (Kerr et al., 1972; Spivak, 1992). In fact, it was estimated that the feral European colonies of honey bees are replaced by Africanized colonies only five years after the start of the Africanization process, although with some remains of the European genotypes (Pinto et al., 2005). The greater proximity of the $F_{1}$ workers and drones to the Africanized parental indicates a stronger influence of African over European genes for the patterns of wing venation, which would help explain the rapid changes in bee morphology that occurred in apiaries and in the wild honey bee population. Quezada-Euán and 
Paxton (1999) observed that there was a strong change in worker wing morphometrics and defensive behavior in European bee colonies after one generation, in an area of Mexico that had been recently colonized by Africanized bees; about $70 \%$ of former European colonies were identified as Africanized, or as Africanized with evidence of European introgression. Other studies have also reported rapid changes in bee morphology at the beginning of the Africanization process at other sites (Boreham and Roubik, 1987; Quezada-Euán and Medina, 1998). Aside from ecological reasons for such dominance, through competitive advantages of Africanized bees (Gonçalves et al., 1991; De Jong, 1996), there appears to be genetic dominance, since based on our morphometric findings the $\mathrm{F}_{1}$ generation is clearly closer to the African parental (Table 1, Figure 3). These rapid changes can also be explained by a greater ontogenetic instability of workers from colonies headed by queens of European maternity mated to drones of Africanized paternity when compared to workers in colonies headed by queens of Africanized maternity mated to drones of European maternity (Schneider et al., 2003). It was also demonstrated that hybrid colonies with matrilineal European origin have a reduced metabolic rate when compared to colonies with African matrilineal origin (Harrison and Hall, 1993).

The canonical analysis graphical disposition of the drones (Figure 2) shows that the $F_{1}$ is significantly closer to the Africanized parental. As drones are haploid, an intermediate position was expected, since all the alleles present in the individuals are expressed. The greater proximity to the Africanized parental group could be due to epistatic influence of other genes on wing vein positioning, as suggested by Rinderer et al. $(1990,1993)$. This is also the first report of geometric morphometric analysis of drones.

Among workers, the proximity of the $\mathrm{F}_{1}$ progeny to the Africanized parental type and the partial superposition of this group on the Africanized backcross group (Figure 3) probably reflect what happened at the beginning of the Africanization process, during which these types of crosses would have been very common. It is known that African colonies produce a greater number of drones and that these drones have a series of advantages when compared to European drones (for a revision, see Schneider et al., 2004).

Our findings help to explain the rapid changes in the morphology of bees in European colonies in recently colonized areas (Boreham and Roubik, 1987; Quezada-Euán and Paxton, 1999) and also provide evidence for dominance and epistatic action of African alleles of the genes responsible for wing vein positioning.

\title{
ACKNOWLEDGMENTS
}

\author{
Research supported by CAPES, CNPq and FAPESP (\#2011/07857-9 to T.M. Francoy).
}

\section{REFERENCES}

Boreham MM and Roubik DW (1987). Population change and control of Africanized honey bees (Hymenoptera: Apidae) in the Panama Canal area. Bull. Entomol. Soc. Am. 33: 34-39.

Daly HV and Balling SS (1978). Identification of Africanized honeybees in the Western hemisphere by discriminant analysis. J. Kans. Entomol. Soc. 51: 857-869.

Daly HV, Hoelmer K, Norman P and Allen T (1982). Computer-assisted measurement and identification of honey bees. Ann. Entomol. Soc. Am. 75: 591-594.

De Jong D (1996). Africanized honey bees in Brazil, forty years of adaptation and success. Bee World 77: 67-70.

Francoy TM, Prado PRR, Gonçalves LS, Costa LF, et al. (2006). Morphometric differences in a single wing cell can discriminate Apis mellifera racial types. Apidologie 37: 91-97. 
Francoy TM, Wittmann D, Drauschke M, Müller S, et al. (2008). Identification of Africanized honey bees through wing morphometrics: two fast and efficient procedures. Apidologie 39: 488-494.

Francoy TM, Wittmann D, Steinhage V, Drauschke M, et al. (2009). Morphometric and genetic changes in a population of Apis mellifera after 34 years of Africanization. Genet. Mol. Res. 8: 709-717.

Gonçalves LS (1970). Análise Genética do Cruzamento Entre Apis mellifera ligustica e Apis mellifera adansonii. Escolha e Análise Genética de Caracteres Morfológicos da Cabeça e do Tórax. PhD thesis, Faculdade de Medicina de Ribeirão Preto, Universidade de São Paulo, Ribeirão Preto.

Gonçalves LS (1974). The introduction of the African bees (Apis mellifera adansonii) into Brazil and some comments on their spread in South America. Am. Bee J. 114: 414-419.

Gonçalves LS, Stort AC and De Jong D (1991). Beekeeping in Brazil. In: The African Honey Bee (Spivak M, Fletcher DJC and Breed MD, eds.). Westview Press, Boulder, 283-296.

Harrison JF and Hall HG (1993). African-European honeybee hybrids have low nonintermediate metabolic capacities. Nature 363: 258-260.

Kerr WE (1967). The history of the introduction of African bees to Brazil. S. Afr. Bee J. 39: 3-5.

Kerr WE, Gonçalves LS, Blotta LF and Maciel JB (1972). Biologia Comparada entre Abelhas Italianas (Apis mellifera lingustica), Africanas (Apis mellifera adansonii) e suas Híbridas. In: Anais do $1^{\circ}$ Congresso Brasileiro de Apicultura. Florianópolis, 80-87.

Pinto MA, Rubink WL, Patton JC, Coulson RN, et al. (2005). Africanization in the United States: Replacement of feral European honeybees (Apis mellifera L.) by an African hybrid swarm. Genetics 170: 1653-1665.

Quezada-Euán JJG and Medina LM (1998). Hybridization between European and Africanized honeybees (Apis mellifera L.) in tropical Yucatan, Mexico. I. Morphometric changes in feral and managed colonies. Apidologie 29: 555-568.

Quezada-Euán JJG and Paxton RJ (1999). Rapid intergenerational changes in morphology and behavior in colonies of Africanized and European honey bees (Apis mellifera) from tropical Yucatan, Mexico. J. Apicult. Res. 38: 93-104.

Rinderer TE, Sylvester HA, Brown MA, Villa JD, et al. (1986). Field and simplified techniques for identifying Africanized and European honey bees. Apidologie 17: 33-48.

Rinderer TE, Daly HV, Sylvester HA, Collins AM, et al. (1990). Morphometric differences among Africanized and European honey bees and their F hybrids (Hymenoptera: Apidae). Ann. Entomol. Soc. Am. 83: 346-351.

Rinderer TE, Buco SM, Rubink WL, Daly HV, et al. (1993). Morphometric identification of Africanized and European honey bees using large reference populations. Apidologie 24: 569-585.

Rohlf FJ (2005a). tpsDig, Version 2.04. Department of Ecology and Evolution. State University of New York, Stony Brook.

Rohlf FJ (2005b). tpsRelw, Version 1.42. Department of Ecology and Evolution. State University of New York, Stony Brook.

Schneider SS, Leamy LJ and De Grandi-Hoffman G (2003). The influence of hybridization between African and European honeybees, Apis mellifera, on asymmetries in wing size and shape. Evolution 57: 2350-2364.

Schneider SS, Hoffman GD and Smith DR (2004). The African honey bee: factors contributing to a successful biological invasion. Аnпu. Rev. Entomol. 49: 351-376.

Sheppard WS, Soares AEE, De Jong D and Shimanuki H (1991). Hybrid status of honey bee populations near the historic origin of Africanization in Brazil. Apidologie 22: 643-652.

Spivak M (1992). The relative success of Africanized and European honey bees over a range of life-zones in Costa Rica. J. Appl. Ecol. 29: 150-162. 